\title{
Convergence of VAT Rates Between 1995 and 2010
}

\author{
Květa Kubátová ${ }^{*}-$ Pavla Holešovská**
}

\section{Introduction}

Since the beginning of European integration, there have been efforts for tax harmonization (development of European legislation and VAT cf. Europa (2014). Firstly, there were efforts for so-called total harmonization; it means harmonization of tax rates as well as the entire structure of tax system (so-called structural harmonization). After unsuccessful attempts, the European Commission reassessed its intention and approached so-called partial harmonization. The Commission decided that only such provisions will be harmonized which would obstruct a smooth function of home market. It was decided in the sphere of indirect taxes (based on several studies - e.g. Neumark's report from 1962) that it is not sufficient only to harmonize indirect taxes but it is necessary that all the member states establish the value added tax which was applied only in France by that time. A period of issuing directives followed. These directives regulated (more or less similarly) various spheres of the value added tax (e.g. object and base of a tax, tax exemption). In 1992 even the range and number of value added tax rates was harmonized. It was set that a member state can use one standard rate of the value added tax. Its range was max. $15 \%$. It was also stated that except for the standard rate, it is possible to apply max. two reduced rates which value was not lower than $5 \%$. These conditions have been valid till nowadays.

The analysis of development of the EU legislation (Europa, 2014) concerning VAT object shows that its form did not change from 1995 till

\# The contribution was made thanks to the project No. V̌́E IP100040 performed at the Faculty of Finance and Accounting, University of Economics, Prague.

prof. Ing. Květa Kubátová, CSc. - Professor; University of Economics, Prague, W. Churchill Sq. 4, 13067 Prague 3, Czech Republic, <kubatova@vse.cz>,

** Ing. Pavla Holešovská - Ph.D. Student; University of Economics, Prague, W. Churchill Sq. 4, 13067 Prague 3, Czech Republic, <pavla.holesovska@ centrum.cz>. 
2013. There were no fundamental changes also in the sphere of tax base form or special regimes, e.g. for small companies. During the mentioned period, exceptions, which were and are still negotiated by member states, were changed. These exceptions are related to the usage of reduced and so-called super-reduced rates and tax objects included in these rates. Generally, we can say that the area of modifications of individual partial spheres did not change significantly from 1995 to 2013. There were some cases where exceptions were reduced for individual member states but there were more cases where the number of exceptions increased.

However, the list of items, which can be filed in the reduced tax rate, (mainly locally provided services with a high share of human labour) has been expanded over the years.

The target of harmonization of indirect taxes is removal of tax obstructions for goods free movement. The European Commission monitors the policy of indirect taxes in individual member states, suggests modifications of the European legislation and regularly evaluates the development of selected indexes (you can find the last issue of statistics and their evaluation in European Commission, 2014). This evaluation monitors also statistics of variability (standard deviations and variation coefficients) but only to the extent of descriptive statistics and statistical induction is omitted.

Šinkýřová (2012) concentrates on the variability of VAT EU 6, EU 15 and EU 27 and its development since the seventieth. In spite of VAT harmonization and the fact that the international trade has developed, there are still differences and EU 27 still includes countries with historical differences in tax rates; this implies, despite the decrease in variation, the coefficient will not approach a zero value and will be higher for EU 27 than for EU 6.

The European Commission pays an extraordinary attention to tax changes and provisions in member countries during the crisis period as a reaction to crisis (the last analysis of this type originates in 2013 (European Commission, Directorate-General for Economic and Financial Affairs, 2013). The last mentioned publication shows that member countries have a different reaction to crisis in tax matters, the policy is expansive as well as restrictive (for terms "expansive" and "restrictive" fiscal policy see e.g. Hamerníková, aj., 2010) and there is an increase as well as decrease of indirect taxes in different countries in different crisis years. The first crisis period $(2008-2010)$ is of course also reflected in the results of the present article (see Figures $1-4$ below). 
The article is organized as follows. Firstly, descriptive statistics of the development of investigated indexes of consumption taxation are mentioned, then a text with executed statistical tests of hypotheses about the conformity of variance and mean (or median) of these indexes during the period 1995 and 2010 follows. Analyses are elaborated in the statistical program Statgraphics. The Conclusion summarizes the results of executed analyses.

\section{Descriptive statistics 1995 - 2010}

The standard tax rate in the EU countries increased at the average from 19.2 to $20.4 \%$ during the period 1995 and 2010. In spite of this fact there are such member countries that reduced the rates in the given period, e.g. the Czech Republic. In 1995 the rate was around 15 up to $25 \%$ but it changed in 2010. The development of average range of the standard rate is depicted in Figure 1. Rapid increase after 2008 comes down to the stabilization of public budgets during the crisis period on the part of governments.

Fig. 1: Development of the average standard rate of value added tax in EU-27 during 1995 and 2010 in \%

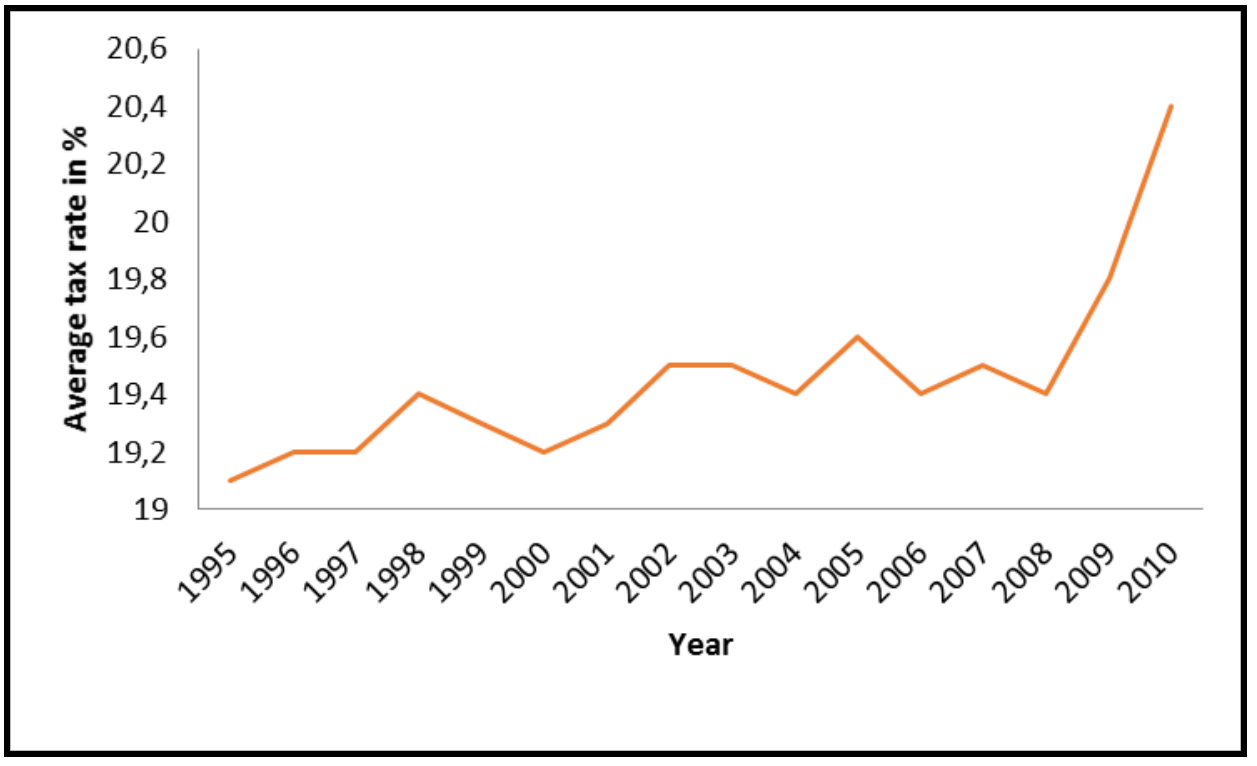

Source: European Commission (2014), own elaboration.

Note: The unweighted average was used for the calculation of average rate. 
The average amount of reduced VAT rate fluctuated from 1995 to 2005 - it decreased in some year but increased in another one, as we can see in Figure 2. We can register a rapid increase even till 2008. The explanation is the same as in case of the average standard VAT rate, i.e. financial crisis.

\section{Fig. 2: Development of the average reduced rate of value added tax during 1995 and 2010 in \%}

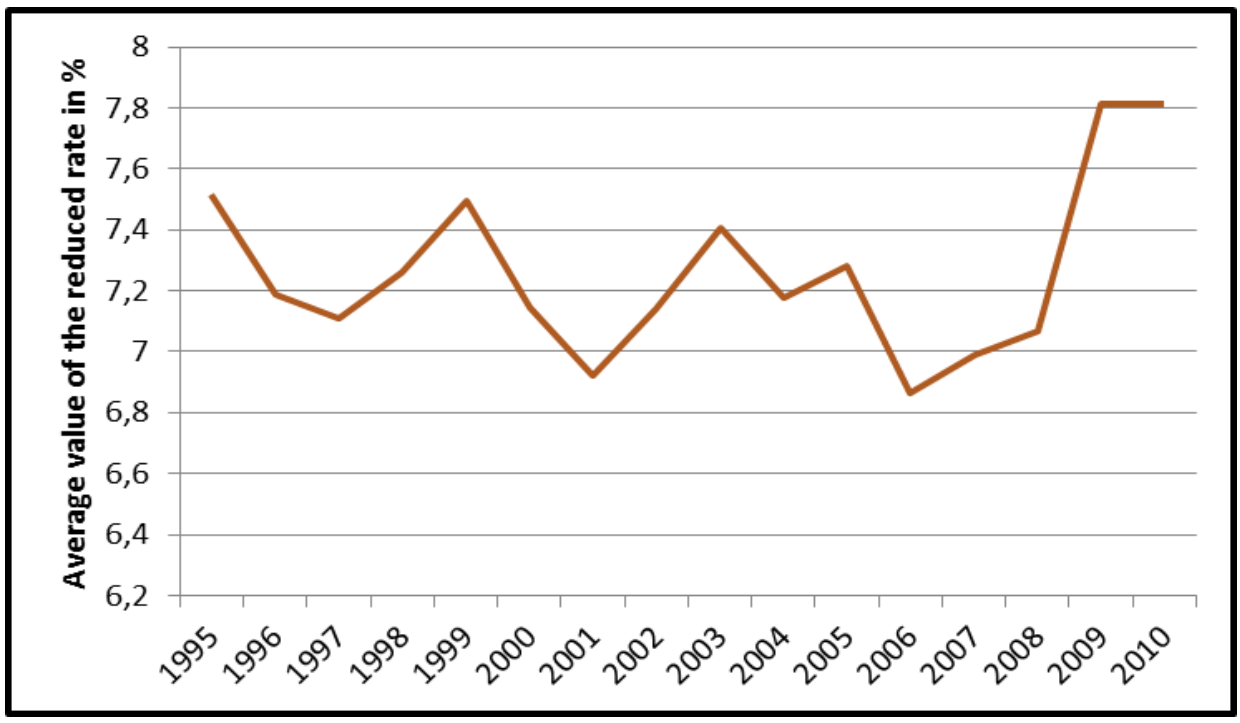

Source: European Commission (2014), own elaboration. An average was used for countries, which have more reduced rates.

Note: The unweighted average was used for the calculation of average rate.

In 2010 the directive of max. 2 reduced rates was fulfilled in all EU countries as compared to 1995 . So-called super-reduced rates were also applied in a smaller extent. Some countries also used a zero rate or socalled parking rate (for the transition period of tax object shift from the reduced to standard rate).

Generally, we can state that the share of VAT in GDP has been increasing over the years. This statement can be proven also in Figure $3-$ development of the average amount of VAT and GDP during 1995 and 2010 in 27 member countries of the EU. As we can see in the figure, the average share of VAT in GDP was growing more or less up to 2006. Since 2006 the situation has changed and the average index started to decline. The biggest decline was in 2009 when the amount declined by 3 
percentage points as compared to the previous year. This big fall was caused by the financial crisis that hit the EU in full force in the second half of 2008. In 2010 the economic situation started to improve slowly and the average amount between VAT and GDP started to increase again.

Recently, various opinions have appeared which state that it is better to tax consumption more than incomes. There are several reasons. Progressive direct taxation demotivates taxpayers from work. Double taxation of savings can be also considered as a negative factor in case of direct taxation. It means that the income tax is applied to revenues from savings twice. Firstly, it is applied to the income and a smaller amount remains taxpayer for savings or consumption. Then it is applied directly to revenues from savings. This implies that the consumption tax is more comfortable for a taxpayer because it brings him higher net revenues (Kubátová, 2010, pp. 95). Another argument for higher taxation by consumption taxes is the fact that consumption taxation has lower costs for administration. Indirect taxes are collected by a smaller number of taxpayers and this makes the entire process of consumption taxes' collection more effective and decreases the possibility of tax evasions.

\section{Fig. 3: Average share of VAT in GDP during 1995 and 2010 in \%}

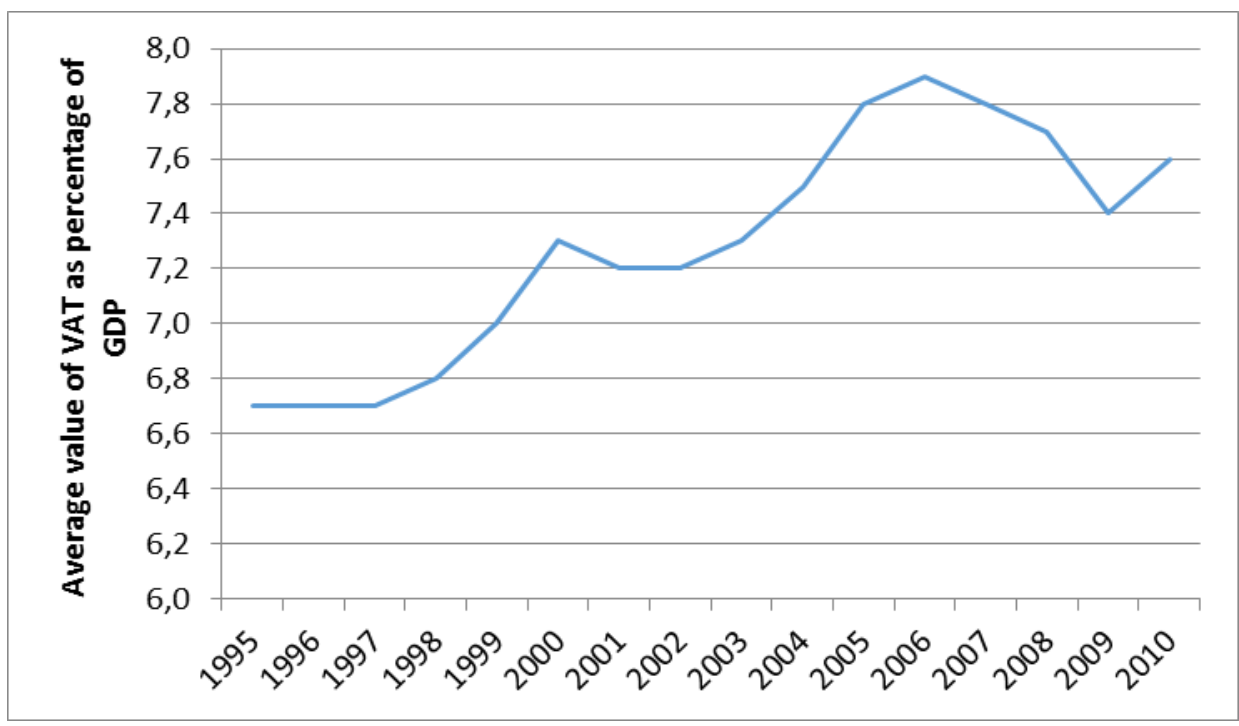

Source: European Commission (2012); own elaboration.

Note: The figure contains the arithmetical mean of EU-27. Data for Greece during 2003 - 2010 is only preliminary. The unweighted average was used for the calculation of average rate. 
So-called implicit tax rates (hereinafter referred to as ITR) are used for the measurement of real tax burden of various economic activities and incomes in the EU (European Commission, 2014). ITR per consumption is set as a share of total tax revenues from consumption in a potential tax base, i.e. consumption.

Development of implicit tax rates per consumption in the EU from 1995 to 2010 is depicted in Figure 4. The amount of average ITRc rate in the EU has been decreasing or increasing over the years according to the current situation in the home market and in the world but the total trend is a growing one.

\section{Fig. 4: Implicit tax rates per consumption during 1995-2010 in \%}

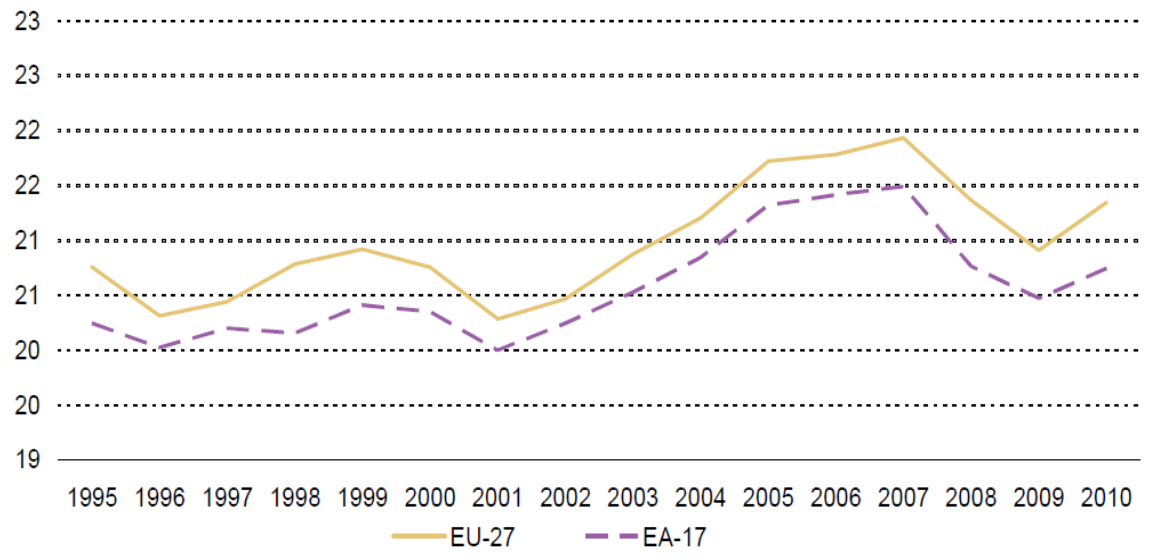

Source: European Commission (2012); own elaboration.

Note: In case that the data is missing for some member countries for the given year, the most current available data is used. The unweighted average was used for the calculation of average rate.

The calculation of ITR does not include only VAT but also other taxes charged on consumption (mainly consumption taxes) but these ones create only a smaller part.

In 2010 the ITR variation range per consumption was substantial, the rate was about 15 up to $31 \%$ in the member countries considering the fact that since 1995 differences among countries have not changed (from 14 to $31 \%)$. 


\section{Tests of significance}

To generalize the results of the previous text the mathematical statistics is used, concretely the method of F-test (or the test of differences of two variances). It is important to realize that the F-test assumes a normal data distribution and if the data does not have a normal distribution, this method cannot be used.

We set the null hypothesis for needs of the F-test as follows:

$$
\mathrm{H}_{0}: \sigma_{1}{ }^{2}=\sigma_{2}^{2}
$$

The calculation of F-test is based on the data of two selective files, which are subjects to comparison - usually it is an experimental and check file. We suppose that each file comes from the population with Gaussian normal distribution with parameters $\mu$ (mean) and $\sigma^{2}$ (variance). Then we set alternative unilateral hypothesis:

$$
\mathrm{H}_{1}: \sigma_{1}^{2}>\sigma_{2}^{2}
$$

The unilateral hypothesis was chosen because we suppose the convergence of tax systems due to harmonization (and also in consequence of the operation of simple market or in consequence of tax competition among countries).

The second test is a paired T-test. The paired T-test indicates if the change of mean can be considered as a statistically important one.

Null hypothesis is:

$$
\mathrm{H}_{0:} \mu_{1}=\mu_{2}
$$

Alternative unilateral hypothesis has the following form:

$$
\mathrm{H}_{1}: \mu_{1}<\mu_{2}
$$

In case of tests of means, we choose the unilateral hypothesis because the long-term tax policy of the EU as well as member countries aims to consolidation of indirect taxes that are less transparent, at the expense of labour and capital taxes, which are very distortionary.

The level of significance was chosen for $5 \%$. Calculations were made by means of statistical software called Statgraphics.

Table 1 shows that the average value of standard rates increased significantly in 2010 as regards statistics. In this case there was an increase from $19.08 \%$ to $20.44 \%$. Hand in hand with grow of the 
average standard tax rate the minimal value increased too - from $8 \%$ to $15 \%$. The reason is the fact that Cyprus entered into the EU in 2004 therefore the minimal limit of $15 \%$ was not applied to this country in 1995. In 2010 all the countries met this limit for the standard rate. The maximal value did not change; Denmark, Sweden and Hungary applied the standard tax rate of $25 \%$ in both years.

The variability of standard rate decreased, the variation coefficient fell from 20.2 to 12.8 and the difference is again statistically significant. Therefore we indicate that there are real powers for the convergence of standard VAT rates in the EU. But regarding the fact that since 1993 the sphere of directive regulating the standard rate has not change (the minimal standard rate should be $15 \%$ ), it is not any administrative harmonization, which leads to the convergence of rates. A more probable explanation is provided by the possibility of tax competition among countries or so-called "demonstration effect" which means that it is advisable to regulate legal tax rates according to other countries, because of political reasons.

In 2010 there was no statistically important difference as regards the mean of reduced VAT rates as compared to 1995. Unfortunately, it was impossible to make the F-test because the distribution was not normal.

The tests imply that the average value of the VAT share in GDP has increased since 1995. There can be several reasons. For instance, more countries started to apply VAT because of their entry into the EU. In addition to that, countries started to prefer indirect taxes more because of their smaller influence on employment and economic activity and easier way of collection during this whole period. Influences of the standard and reduced rate, ways of classification of goods and services into one of these rates and influences of GDP changes group together in the index of VAT share in GDP. In spite of the fact that a significant index - standard rate - converges, the VAT share in GDP does not have to converge, as proven by the test.

As regards ITRc, we can state that the average value of implicit tax rate per consumption neither changed significantly in the EU countries during 1995 and 2010, as regards statistics, nor was there any convergence of this index among countries. We can assume that the above-mentioned statement could be explained by the fact that many member countries still keep individual setting of classification of goods and services into the reduced rate, if the directive allows it, and there are also many exceptions from the directive that causes keeping considerable 
differences in effective taxation in the member states. As regards the ITR index, it was necessary to use the total taxation of consumption - ITRc that includes not only VAT but also other consumption taxes. Therefore it does not have to correspond completely to VAT rates (EU statistics, European Commission, 2014, does not state ITR separately for VAT and consumption taxes because of logical reasons).

The following table summarizes results of the entire analysis.

Tab. 1: Test results of the conformity of variances and means (comparison of values in the EU countries in 1995 and 2010)

\begin{tabular}{|c|c|c|c|c|c|c|c|}
\hline \multirow[t]{2}{*}{ Index } & \multicolumn{2}{|c|}{$\begin{array}{c}\text { Average } \\
\text { value in \% }\end{array}$} & \multicolumn{2}{|c|}{$\begin{array}{l}\text { Variation } \\
\text { coefficient } \\
\text { in } \%\end{array}$} & \multirow[t]{2}{*}{ F-test ${ }^{1}$} & \multirow[t]{2}{*}{ T-test ${ }^{2}$} & \multirow[t]{2}{*}{$\begin{array}{l}\text { Sign } \\
\text { test }^{3}\end{array}$} \\
\hline & 1995 & 2010 & 1995 & 2010 & & & \\
\hline $\begin{array}{l}\text { Standard } \\
\text { VAT rate }\end{array}$ & 19.1 & 20.4 & 20.2 & 12.8 & $\begin{array}{c}\text { We reject } \\
\mathrm{H}_{0}\end{array}$ & $\begin{array}{c}\text { We reject } \\
\mathrm{H}_{0}\end{array}$ & - \\
\hline $\begin{array}{l}\text { Reduced } \\
\text { VAT rate }^{6}\end{array}$ & 7.5 & 7.8 & 40.4 & 35.8 & $\begin{array}{l}\text { It cannot } \\
\text { be } \\
\text { performed }\end{array}$ & $\begin{array}{c}\text { We reject } \\
\mathrm{H}_{0}\end{array}$ & - \\
\hline $\begin{array}{c}\text { VAT revenue } \\
\text { as percentage } \\
\text { of GDP }\end{array}$ & 6.9 & 7.6 & 20.1 & 15.2 & $\begin{array}{l}\text { We do not } \\
\text { reject } \mathrm{H}_{0}\end{array}$ & $\begin{array}{l}\text { It cannot be } \\
\text { performed }\end{array}$ & $\begin{array}{l}\mathrm{We} \\
\text { reject } \\
\mathrm{H}_{0} \\
\end{array}$ \\
\hline $\begin{array}{c}\text { ITR per } \\
\text { consumption }\end{array}$ & 20.9 & 21.3 & 23.2 & 20.1 & $\begin{array}{l}\text { We do not } \\
\text { reject } \mathrm{H}_{0}\end{array}$ & $\begin{array}{l}\text { We do not } \\
\text { reject } \mathrm{H}_{0}\end{array}$ & - \\
\hline
\end{tabular}

Source: European Commission (2012), European Commission (2014), own elaboration.

Note: tests were made at $5 \%$ level of significance. 1 Hypotheses for the purpose of the F-test were set as follows: H0: $\partial 12=\partial 22 ; \mathrm{H} 1: \partial 12>\partial 22.2$ Hypotheses of the T-test were set as follows: $\mathrm{H} 0: \mu 1=\mu 2 ; \mathrm{H} 1: \mu 1<\mu 2.3$ Hypotheses for the purpose of the sign test were set as follows: H0: median $1=$ median2; H1: median $1<\operatorname{median} 2.4$ Greece is not included because of data absence from 1995. 5 Slovenia is not included because this country imposed VAT only in 1999. 6 Slovenia is not included because this country imposed VAT only in 1999; if the reduced rate did not exist in some country in some of the mentioned years (6 countries in 1995 and one country in 2010), this country was not included in the analysis of that year. 


\section{Conclusion}

If we summarize the results of the executed analysis, we can state that except for standard VAT rates, the variability did not decline and tax systems did not converge. Often proclaimed trend of grow of tax burden by indirect taxes was confirmed in case of standard tax rates and share of VAT in GDP. The growth was not statistically important in the remaining cases.

The comparison of the above-mentioned results with the development of VAT legislation in the European Union is interesting too, for sure. Since 1995 the legal form of VAT in the EU has not practically changed, only several details were added and the number of exceptions increased because of the entry of new member states. In spite of this fact we can see that tax systems have converged as regards e.g. standard tax rates. Because of the simple home market, competition among individual member states increased. It became important in the open European Union, where it is possible to change easily the residence from one member state to another one, not only to realize tax intensions in compliance with the European legislation but also monitor and evaluate intensions of other countries and modify own intensions concerning tax policy according to that.

\section{References}

Europa (2014): Summaries of EU legislation. [on-line], [cited $5^{\text {th }}$ April 2014] , <http://europa.eu/legislation_summaries/taxation/index_en.htm>

European Commission (2012): Taxation trends in the European Union, 2012. [on-line], [cited $1^{\text {st }}$ May 2014], <http://ec.europa.eu/taxation _customs/resources/documents/taxation/gen_info/economic_analysis/tax_ structures/2012/report.pdf>

European Commission (2013): Taxation trends in the European Union, 2013. [on-line], [cited $1^{\text {st }}$ May 2014], <http://ec.europa.eu/taxation _customs/resources/documents/taxation/gen_info/economic_analysis/tax _ structures/2013/report.pdf>

European Commission (2014): VAT rates applied in the member states of the European Union, 2014. [on-line], [cited 1 ${ }^{\text {st }}$ May 2014], $<$ http://ec.europa.eu/taxation_customs/resources/documents/taxation/vat/h ow_vat_works/rates/vat_rates_en.pdf $>$

European Commission, Directorate-General for Economic and Financial Affairs (2013): Tax reforms in EU member states 2013: Tax policy 
challenges for economical growth and fiscal sustainability [on-line]. Luxembourg: Publications office of the European Union, 2013. ISBN 978-92-79-33025-4, ISSN 1725-7557, DOI 10.2778/17282. [cited $5^{\text {th }}$ January 2014], <http://ec.europa.eu/taxation_customs/resources/ /taxation/gen_info/economic_analysis/tax_papers/taxation_paper_38.pdf> Hamerníková, B., at al. (2010): Verejné finance, $2^{\text {nd }}$ current edition. Praha: Wolters Kluwer, 2010, pp. 340. ISBN 978-80-7357-497-0, $<$ http://eso.vse.cz/ sklenak/pcvse/pcvse-sfx.php?krestni=Alena\&prijmeni $=$ MAAYTOV $\%$ C $1 \&$ katedra $=\mathrm{KVF}>$

Kubátová, K. (2010): Daňová teorie a politika, $5^{\text {th }}$ edition. Praha: Wolters Kluwer ČR, 2010, pp. 275, ISBN 978-80-7357-574-8.

Šinkyř́ková, T. (2012): Variability of VAT rates; presumptions and evidence. In Špalková D. - Furová L. Proceedings of the $16^{\text {th }}$ International Conference Modern and Current Trends in the Public Sector Research, $1^{\text {st }}$ edition. Brno, 2012, pp. 137-145, pp. 9. ISBN 978-80-210-5822-4. 


\title{
Convergence of VAT Rates Between 1995 and 2010
}

\begin{abstract}
Consumption taxes have been harmonized in the EU countries since 1993 and a great attention is paid to their convergence in the EU. The EU directives harmonize tax administration, tax bases and set minimal applicable rates. The aim of the article is to find out if VAT systems of the EU countries really converged during the period 1995 and 2010, in consequence of harmonization.

The subject of investigation is standard and reduced VAT rates, VAT revenues as a share in GDP and implicit rates of consumption taxes. Investigative methods are analysis of these indexes' development, t-tests and F-tests. There were used data from Eurostat and the European Commission for the statistics. Except for standard VAT rates, there was no decrease of indexes' variability and therefore tax systems did not converge.
\end{abstract}

Key words: Value added tax; The European Union; Convergence of VAT rates; VAT harmonization; F-test.

JEL Classification: H20 